Article

\title{
Dietary Effects of Carotenoid on Growth Performance and Pigmentation in Bighead Catfish (Clarias macrocephalus Günther, 1864)
}

\author{
Tran Thi Thanh Hien, Trinh Van Loc, Tran Le Cam Tu, Tran Minh Phu, Pham Minh Duc, Hua Thai Nhan \\ and Pham Thanh Liem *(D)
}

check for updates

Citation: Hien, T.T.T.; Loc, T.V.; Tu, T.L.C.; Phu, T.M.; Duc, P.M.; Nhan, H.T.; Liem, P.T. Dietary Effects of Carotenoid on Growth Performance and Pigmentation in Bighead Catfish (Clarias macrocephalus Günther, 1864). Fishes 2022, 7, 37. https://doi.org/ 10.3390/fishes7010037

Academic Editor: Pedro Gómez-Requeni

Received: 7 November 2021

Accepted: 1 February 2022

Published: 4 February 2022

Publisher's Note: MDPI stays neutral with regard to jurisdictional claims in published maps and institutional affiliations.

Copyright: (C) 2022 by the authors. Licensee MDPI, Basel, Switzerland. This article is an open access article distributed under the terms and conditions of the Creative Commons Attribution (CC BY) license (https:// creativecommons.org/licenses/by/ $4.0 /)$.
College of Aquaculture and Fisheries, Can Tho University, Campus II, $3 / 2$ Street, Ninh Kieu District, Can Tho City 900000, Vietnam; ttthien@ctu.edu.vn (T.T.T.H.); tvloc@ctu.edu.vn (T.V.L.); tlctu@ctu.edu.vn (T.L.C.T.); tmphu@ctu.edu.vn (T.M.P.); pmduc@ctu.edu.vn (P.M.D.); htnhan@ctu.edu.vn (H.T.N.) * Correspondence: ptliem@ctu.edu.vn; Tel.: +84-0292-3830642

\begin{abstract}
This study investigates the effects of supplemental carotenoid pigments on growth and color performance in bighead catfish (Clarias macrocephalus). Two experiments were undertaken to determine the appropriate types, feed duration, and dose of astaxanthin (As), canthaxanthin (Ca), and xanthophyll $(\mathrm{Xa})$ pigments individually and in combination. In the first experiment, fish were fed with one control diet (basic diet), six experimental diets comprised of three diets of As, $\mathrm{Ca}$, and $\mathrm{Xa}$ at a $100 \mathrm{mg} / \mathrm{kg}$ rate of supplementation, respectively, and three diets combinations of $\mathrm{As}+\mathrm{Ca}$, $\mathrm{As}+\mathrm{Xa}$, and $\mathrm{Ca}+\mathrm{Xa}$ at a supplement rate of $50 \mathrm{mg}+50 \mathrm{mg} / \mathrm{kg}$. The results showed no significant difference in weight gain (WG), specific growth rate (SGR), survival rate (SR), and feed conversion ratio of fish among treatments $(p>0.05)$ after 6 weeks. The $L^{*}$ (Lightness) and $a^{*}$ (redness) values in the Xa diet were significantly lower than other treatments, while $b^{*}$ (yellowness) was significantly higher than in the control and others treatments $(p<0.05)$. These values peaked after 4 weeks and remained stable until the end of the experiment. Consistently, the highest muscle carotenoid content $(16.89 \pm 0.60 \mathrm{mg} / 100 \mathrm{~g})$ was found in the fish fed with the Xa diet. The Xa diet was selected for the second experiment. This experiment consisted of four Xa supplemented diets at rates of 25, 50, 75, and $100 \mathrm{mg} / \mathrm{kg}$ and a basal diet without any Xa supplementation. The results showed that there was no difference in the SGR or SR of fish fed various Xa levels $(p>0.05)$. Fish fed the Xa diet of $75 \mathrm{mg} / \mathrm{kg}$ were the most preferred by consumers for the natural "yellowness" of muscle. Thus, the results suggested that additional carotenoid pigments did not affect the growth performance of fish. Farmers and feed producers could utilize $\mathrm{Xa}$ at an optimal dose of $75 \mathrm{mg} / \mathrm{kg}$ to enhance color performance in the market size of bighead catfish for at least 4 weeks prior to harvest.
\end{abstract}

Keywords: carotenoids; Clarias macrocephalus; skin color; muscle yellowness; xanthophyll

\section{Introduction}

Bighead catfish Clarias macrocephalus is one of the most popular and economically important indigenous fish in Southeast Asia [1-5]. The fish has become one of the most important freshwater species for the aquaculture industry in Vietnam [3-5]. The market values of this fish not only depend on meat quality and taste but also rely on skin and muscle pigmentation performance. Buyers and consumers alike prefer good quality bighead catfish to have yellowish skin and muscle tone. This is the most important characteristic of fish quality at the market. Other studies reported that the color of the fish is the first characteristic perceived and is a determinant selection criterion, directly related to subsequent acceptance or rejection [6,7].

Farmed bighead catfish typically exhibit pale muscle color and do not have the natural attractive color found in wild fish. This issue negatively affects profitability for farmers because of reduced market prices and reduced consumer demand. To overcome this issue, 
numerous applications have been carried out by farmers, such as diet supplementation with raw carotenoid ingredients such as pumpkin, sweet potato, and carrot [4,5]. However, these applications did not provide any successful color improvement of the fish due to faded color results.

Similar to other species, bighead catfish are not able to synthesize their own coloring pigments de novo. The coloring pigments are related to carotenoid supplementation and need to be incorporated into the diet [8,9]. In the wild, fish acquire pigments from natural foods such as algae, crustaceans, etc. However, natural food varies the number of carotenoids. The carotenoid pigments, astaxanthin, canthaxanthin, and xanthophyll, are widely used in aquafeed [10]. The addition of these pigments to diets has been shown to enhance color and growth performance, improve survival rate, and reduce stress [11-13].

Studies have shown that incorporating synthetic carotenoid pigments or natural carotenoid-rich feed ingredients into fish diet enhances the growth and color performances of different fish [12,14-18]. However, the optimum dietary supplementation level for each of the carotenoid pigments (canthaxanthin, astaxanthin, xanthophylls) is species-specific. The application of canthaxanthin or astaxanthin has been shown to be effective on rainbow fillets Oncorhynchus mykiss at a dietary supplementation level of $80 \mathrm{mg} / \mathrm{kg}$ of diet [19]. Other studies have found that both xanthophylls and astaxanthin (37.7-75 mg/ $\mathrm{kg}$ of diet) were effective carotenoid sources for skin color improvement in large yellow croaker Larimichthys croceus [12]. However, there is currently a lack of knowledge and scientific literature on the effect of these carotenoids on the color performance of bighead catfish C. macrocephalus. Therefore, the purpose of this study was to examine the appropriate carotenoid pigment, supplemental dose, and administration period on the growth and color performances of bighead catfish C. macrocephalus.

\section{Materials and Methods}

\subsection{Experimental Fish}

Juvenile bighead catfish $(46.11 \pm 1.19 \mathrm{~g})$ were obtained from a reliable hatchery (Tam Loc hatchery, Can Tho City, Vietnam). Fish were placed in plastic containers with gentle aeration then transferred to the wet lab of the College of Aquaculture and Fisheries, Can Tho University. The fish were acclimatized to the experimental conditions for 2 weeks prior to use for the trial, and they were fed with a basal diet during this period.

\subsection{Experimental Design}

Two experiments were conducted to examine the appropriate dietary pigments supplementation for optimal growth and color performance of bighead catfish.

In the first experiment, fish were fed with seven dietary levels or combinations of astaxanthin (As), canthaxanthin (Ca), and xanthophyll (Xa) (Manufacturer BASF, Germany), including a control diet without additional pigment supplementation (Basic diet only, Table 1). Three diets were supplemented with As, Ca, and Xa at the level of $100 \mathrm{mg} / \mathrm{kg}$ of feed, and three combination diets were supplemented with $50 \mathrm{mg} \mathrm{As}+50 \mathrm{mg} \mathrm{Ca} / \mathrm{kg}$ of feed, $50 \mathrm{mg} \mathrm{As}+50 \mathrm{mg} \mathrm{Xa/kg}$ of feed, and $50 \mathrm{mg} \mathrm{Ca}+50 \mathrm{mg} \mathrm{Xa/kg}$ of feed. Overall, the diets were labelled as control, As, $\mathrm{Ca}, \mathrm{Xa}, \mathrm{As}+\mathrm{Ca}, \mathrm{As}+\mathrm{Xa}$, and $\mathrm{Ca}+\mathrm{Xa}$ diets, respectively. These reference levels were based upon the approved carotenoid pigments level for use in aquaculture feed in the United States and the European Union and range from 80 to $135 \mathrm{mg} / \mathrm{kg}$ of feed (USA: 21CFR Section and EU Code No. (EC, 2003b), regulation No: CD70/524/EEC). 
Table 1. Chemical composition of basal diet (dry matter basis).

\begin{tabular}{|c|c|}
\hline Ingredient & Amount (\%) \\
\hline Fish meal ${ }^{1}$ & 25.0 \\
\hline Defatted soybean meal ${ }^{2}$ & 35.0 \\
\hline Blood meal $^{3}$ & 7.00 \\
\hline Rice bran ${ }^{4}$ & 15.0 \\
\hline Cassava meal $^{5}$ & 14.5 \\
\hline Fish oil 6 & 1.00 \\
\hline Premix mineral and vitamin ${ }^{7}$ & 1.00 \\
\hline Shrimp soluble extract ${ }^{8}$ & 1.00 \\
\hline Guar gum 9 & 0.5 \\
\hline Total & 100 \\
\hline \multicolumn{2}{|c|}{ Proximate analysis (\% as dry matter basis) } \\
\hline Crude Protein & 43.8 \\
\hline Crude Lipid & 6.82 \\
\hline Ash & 11.9 \\
\hline Carbohydrate & 37.5 \\
\hline Gross energy $(\mathrm{KJ} / \mathrm{g})$ & 19.5 \\
\hline
\end{tabular}

${ }^{1}$ Ca Mau fishmeal Vietnam. ${ }^{2}$ Defatted soybean meal Maharashtra Solvent extraction LTD India. ${ }^{3,4,5,6}$ Blood meal, rice bran, fish oil, cassava meal were imported and supplied by Viet Thang feed mill. ${ }^{7}$ Premix khoáng vitamin: Vitamin A. 6,000,000 UI; Vitamin D . 200,000 UI; Vitamin E. 50,000 mg; Vitamin K .6000 mg Vitamin $\mathrm{B}_{1} .11,000 \mathrm{mg}$; Vitamin $\mathrm{B}_{2} .7000 \mathrm{mg}$; B6: Vitamin B6: $8000 \mathrm{mg}$ Vitamin B12. $20 \mathrm{mg}$; Vitamin C Stay. $5000 \mathrm{mg}$ Inositol. $5000 \mathrm{mg}$; Folic acid. $3000 \mathrm{mg}$; Biotin. $500 \mathrm{mg}$; Pantothenic Acid. 35,000 mg; Niacin. 60,000 mg; Iron (Fe ${ }^{2+}$ ).

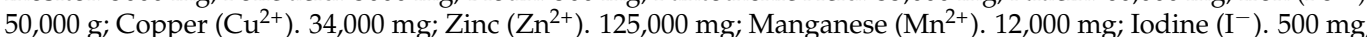
Cobalt $\left(\mathrm{Co}^{2+}\right) .250 \mathrm{mg}$; Se. $200 \mathrm{mg} .{ }^{8}$ Attractant (shrimp solution extract) was made in Minh Phu comp., Vietnam.

${ }^{9}$ Binder (guar gum) was imported from Pakistan and supplied by Hoa chat Can Tho comp., Vietnam.

Feed formulation and proximate analysis of the basal experimental diet are shown in Table 1. This diet meets the optimum nutrient requirement for bighead catfish $[4,5]$. Experimental diets were prepared and processed according to Hien et al. [4,5]. In brief, the ingredients were ground in a hammer mill to pass through a mesh screen size of $0.8 \mathrm{~mm}$. All ingredients were then mixed thoroughly by a mixer. Thereafter, extruded feed $(2.0 \mathrm{~mm})$ was dried in an oven at $45-50{ }^{\circ} \mathrm{C}$ for about $8-10 \mathrm{~h}$ and then stored at $-20^{\circ} \mathrm{C}$ until used. The chemical composition of diets was analyzed following the methods of AOAC [20].

Fish were held in a recirculating experimental tank system at a stocking density of 60 fish $/ 200 \mathrm{~L}$ tank (approximately $13.8 \mathrm{~kg} / \mathrm{m}^{3}$ ). A total of 28 round composite tanks $(250 \mathrm{~L} /$ tank) were used. In total, there were seven recycling systems, each consisting of four experimental tanks and filter tanks of $350 \mathrm{~L}$. Biofilter tanks contained 87.5 litters of biofilter media (RKPlast Bioelement, Brorup, Denmark, surface area $750 \mathrm{~m}^{2} / \mathrm{m}^{3}$ ) and a settlement tank (solid tank) of $120 \mathrm{~L}$. All experimental recirculating systems were prepared at least 21 days prior to use, during which time water flow rates remained constant at $0.8-1 \mathrm{~L} / \mathrm{min}$. The experiment lasted for 6 weeks.

The second experiment, this experiment was designed to assess the effect of xanthophyll pigment on growth and color in bighead catfish. Results from Experiment 1 showed that dietary xanthophyll gave the best improvement in color after 4 weeks. This experiment was carried out to examine the appropriate supplemental doses of xanthophyll pigment for growth and color performance to meet consumer tastes. Fish were fed with five diets consisting of $0.0 \mathrm{mg}$ (Basal diet), 25, 50, 75, and $100 \mathrm{mg} \mathrm{Xa/} / \mathrm{kg}$ of feed, hereafter called control, $25 \mathrm{mg} \mathrm{Xa}, 50 \mathrm{mg} \mathrm{Xa}, 75 \mathrm{mg}$ Xa, and $100 \mathrm{mg} \mathrm{Xa.} \mathrm{The} \mathrm{basal} \mathrm{diet} \mathrm{(Table} \mathrm{1)} \mathrm{and}$ experimental design and set-up were also the same as in Experiment 1 . All experiments were carried out in accordance with national guidelines on the protection and experimental animal welfare in Vietnam, Law of Animal Health, 2015 (Report number: VM5068).

\subsection{Experimental Management}

Experimental fish were fed ad libitum, twice a day at 8:00 a.m. and 16:00 p.m. Water parameters, including water temperature, $\mathrm{pH}$, and dissolved oxygen, were measured twice 
daily at 7:00 a.m. and 15:00 p.m. using a multiple parameters meter (YSI 556, USA) and were maintained within a suitable range for normal growth, i.e., temperature $\left(27.4-31.4{ }^{\circ} \mathrm{C}\right)$, $\mathrm{pH}$ (7.6-8.3), and DO (4.7-5.2 mg/L). Total ammonium nitrogen (TAN) and nitrite-nitrogen were measured weekly and remained at $0.12-0.18 \mathrm{mg} / \mathrm{L} ; 0.1-0.2 \mathrm{mg} / \mathrm{L}$ for the duration of the experiment, respectively.

\subsection{Growth Performance Parameters}

Fish weight was measured at the beginning of the experiment and at two-week intervals until the end of the experiment. Growth performance parameters such as weight gain (WG), specific growth rate (SGR), and survival rate (SR) were calculated using the followings equations:

$$
\begin{gathered}
\text { Weight gain }(\mathrm{WG}, \mathrm{g})=\left(\mathrm{W}_{\mathrm{f}}\right)-\left(\mathrm{W}_{\mathrm{i}}\right) \\
\text { Specific growth rate }\left(\mathrm{SGR}, \% \text { day }^{-1}\right)=\left\{\left(\mathrm{Ln}\left(\mathrm{W}_{\mathrm{f}}\right)-\mathrm{Ln}\left(\mathrm{W}_{\mathrm{i}}\right) / \mathrm{T}\right\} \times 100\right. \\
\text { Survival rate }(\mathrm{SR}, \%)=(\text { Final number of fish }) /(\text { Initial number of fish }) \times 100
\end{gathered}
$$

where: $W_{f}$ and $W_{i}$ are the final and initial wet weight of bighead catfish; $T=$ time duration of the experiment; $\mathrm{Ln}=$ normal logarithm.

\subsection{Skin and Muscle Pigmentation}

The colour performance in bighead catfish was assessed by a combination of three different methods, a colorimeter, sensory assessment methods, and by examining accumulated carotenoids in the muscle of fish as follows:

\subsubsection{Colorimeter Method}

The color change was examined using a CR200 Colorimeter (Minolta Camera Ltd., Osaka, Japan) [21,22]. Fish were measured at the beginning of the experiment and every two weeks until the end of the experiment. Here, 12 fish per treatment ( 3 fish per tank) were assessed. All measurements were shown in the colorimetric space $\mathrm{L}^{*}, \mathrm{a}^{*}, \mathrm{~b}^{*}$ according to Commission Internationale de l'Éclairage guidance [23]. Each measurement determined and recorded standard $L^{*}, a^{*}, b^{*}$ values. The $L^{*}, a^{*}, b^{*}$ values were measured at various positions on each fish (body skin, abdominal skin, and muscle), as shown in Figure 1. Each measurement was repeated three times for body skin, abdominal skin, and muscle. Finally, average color values $L^{*}, a^{*}, b^{*}$ for experimental fish were calculated and recorded. The $L^{*}$ value represents the lightness from black to white on a scale between 0 and 100, while the $a^{*}$ value represents a shade from red $(+)$ to green $(-)$, and the $b^{*}$ value represents shade from yellow $(+)$ to blue $(-)$ in the color measurement of fish.

To evaluate the effect of different treatments on the catfish's color, the mean $\left(\mathrm{L}^{*}, \mathrm{a}^{*}\right.$, $b^{*}$ ) color value of the bighead catfish for each treatment was compared to that of the control group. The comparison metric was the color difference defined by the International Commission on Illumination (CIE) in 1976, which has been extensively applied in various studies related to food color measurement and comparison [24-26]. Accordingly, the mean color difference between a non-control catfish with the mean color $c\left(L^{*}, a^{*}, b^{*}\right)$ and a treated catfish with the mean color $c\left(\mathrm{~L}_{t}^{*}, \mathrm{a}_{\mathrm{t}}^{*}, \mathrm{~b}_{\mathrm{t}}{ }^{*}\right)$ in their $\mathrm{L}^{*}, \mathrm{a}^{*}, \mathrm{~b}^{*}$ color space was calculated as seen in Equation (4).

$$
\Delta \mathrm{E}_{\mathrm{ab}}^{*}=\sqrt{\left(\mathrm{L}^{*}-\mathrm{L}_{\mathrm{t}}^{*}\right)^{2}+\left(\mathrm{a}^{*}-\mathrm{a}_{\mathrm{t}}^{*}\right)^{2}+\left(\mathrm{b}^{*}-\mathrm{b}_{\mathrm{t}}^{*}\right)^{2}}
$$




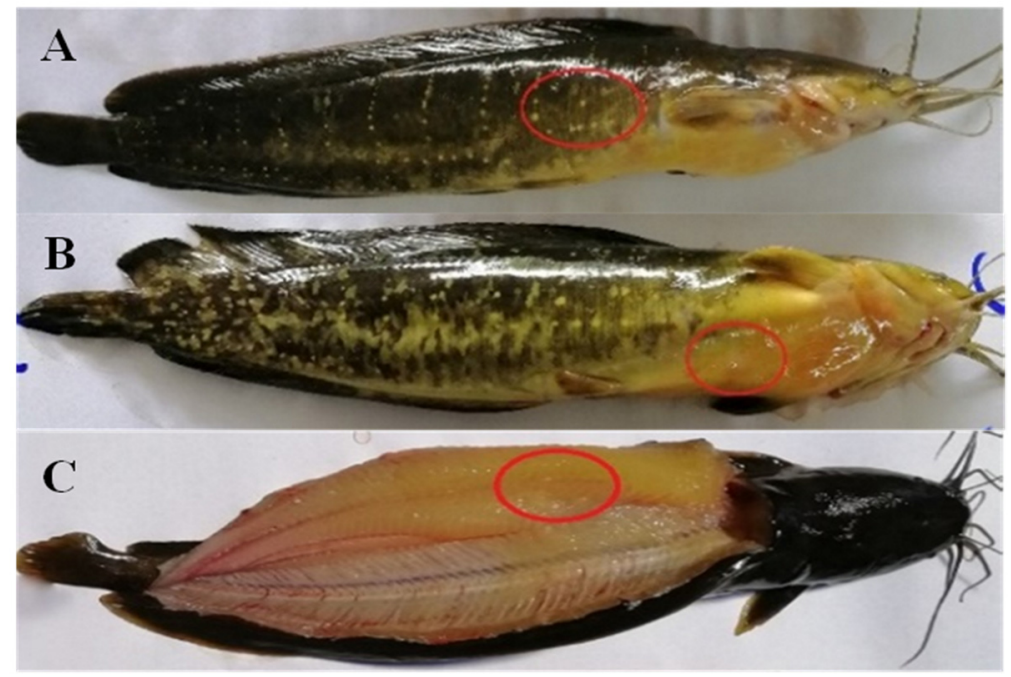

Figure 1. Digital image for site color measurement (circle) of body skin (A), abdominal skin (B), and muscle $(\mathbf{C})$ of bighead catfish.

\subsubsection{Sensory Evaluation Method}

The appearance of bighead catfish color was also assessed through the sensory evaluation method of Meilgaard et al. [27]. The apparent color of the fish was scored on a scale from 1 to 9. The color of the control was scored at 6, while the other experimental samples were coded and scored in comparison. Scores increased more than 6 if the yellow was darker than the control and decreased less than 6 if the yellow color was lighter than the control. This evaluation method was carried out by 10 independent assessors who had normal colour visions and were able to detect anomalies in the appearance of fish in a consistent manner.

\subsubsection{Carotenoid Analysis}

At the end of the experiment, the accumulated carotenoid level in the flesh (muscle tissue and skin) of fish was also analyzed following the method described by previous studies [28,29]. Samples were randomly taken from three fish per tank. After anesthetizing with clove oil, each fish was carefully dissected, and muscle was immediately sampled for carotenoid analysis. Briefly, the flesh samples were randomly collected from 12 fish per treatment (three fish per tank). The flesh samples were frozen at $-20{ }^{\circ} \mathrm{C}$ and then homogenized in frozen conditions using a grinder. Carotenoids were extracted from representative $5.0 \mathrm{~g}$ subsamples using $3 \times 25 \mathrm{~mL}$ of acetone. Acetone extraction was carried out three times until the solvent became colorless. After the addition of the last acetone extraction and lasting for $24 \mathrm{~h}$, the samples were centrifuged at $4000 \mathrm{RPM}$ for $5 \mathrm{~min}$. The absorbance of the extracts was recorded at $470 \mathrm{~nm}$ using a Hitachi U5100 (Tokyo, Japan) spectrophotometer, and the carotenoid concentration $(\mathrm{mg} / \mathrm{mL})$ was determined by reference to a standard curve. The carotenoid concentration in the muscle sample (mg/100 g) was calculated based on the dilution and the weight of muscle samples.

\subsection{Statistical Analysis}

All data were calculated as mean values and standardized deviations (Mean $\pm \mathrm{SD}$ ) using Microsoft Excel 2013. Two factorials analyses of various pigments and times were employed by Two-way ANOVA (IBM SPSS Statistics 21, SPSS Inc., Chicago, IL, USA). Mean comparisons between treatments were made using a one-way ANOVA. Differences between means were evaluated for significant differences by Duncan's test at $p<0.05$. 


\section{Results}

\subsection{Effect of Various Dietary Pigments on Growth and Color Performance of Bighead Catfish}

3.1.1. Growth Performance, Feed Utilization, and Survival Rate

The growth performance, feed utilization, and survival rate of bighead catfish fed with the various dietary pigments are shown in Table 2. The results show that the highest final weight $\left(\mathrm{W}_{\mathrm{f}}\right)$ was found in those fish fed the xanthophyll diet. However, statistical analysis by one-way ANOVA showed no significant difference in specific growth rate (SGR) among the dietary pigments treatments $(p>0.05)$. The average final weight $\left(\mathrm{W}_{\mathrm{f}}\right)$ varied from 56.8 to $59.5 \mathrm{~g} /$ fish, and the SGR fluctuated from 0.35 to $0.43 \% /$ day. High survival rates ranging from 80.8 to $89.2 \%$ were recorded for all treatments.

Table 2. Growth performance, initial weight $\left(W_{i}, g /\right.$ fish), final weight $\left(W_{f}, g /\right.$ fish), specific growth rate (SGR, \%/day), and survival rate (SR, \%) of fish fed dietary pigments for 6 weeks.

\begin{tabular}{ccccc}
\hline Treat. & $\mathbf{W}_{\mathbf{i}}$ & $\mathbf{W}_{\mathbf{f}}$ & $\mathbf{S G R}$ & SR (\%) \\
\hline Control & $46.3 \pm 0.55$ & $57.6 \pm 1.22^{\mathrm{ab}}$ & $0.36 \pm 0.43$ & $80.8 \pm 13.4$ \\
$\mathrm{As}$ & $45.9 \pm 1.06$ & $56.8 \pm 1.40^{\mathrm{b}}$ & $0.35 \pm 0.01$ & $87.9 \pm 3.69$ \\
$\mathrm{Ca}$ & $46.6 \pm 0.46$ & $59.2 \pm 1.43^{\mathrm{a}}$ & $0.39 \pm 0.05$ & $85.4 \pm 4.38$ \\
$\mathrm{Xa}$ & $45.8 \pm 1.63$ & $59.5 \pm 2.04^{\mathrm{a}}$ & $0.43 \pm 0.05$ & $86.7 \pm 3.59$ \\
$\mathrm{As}+\mathrm{Ca}$ & $46.0 \pm 1.79$ & $58.3 \pm 1.08^{\mathrm{ab}}$ & $0.39 \pm 0.09$ & $87.1 \pm 2.84$ \\
$\mathrm{As}+\mathrm{Xa}$ & $46.2 \pm 1.07$ & $58.3 \pm 0.86^{\mathrm{ab}}$ & $0.38 \pm 0.04$ & $89.2 \pm 7.00$ \\
$\mathrm{Ca}+\mathrm{Xa}$ & $45.9 \pm 1.08$ & $58.8 \pm 1.77^{\mathrm{ab}}$ & $0.41 \pm 0.02$ & $87.9 \pm 4.16$ \\
\hline
\end{tabular}

Values are means of four replicates \pm S.D; values with the same letters are not significantly different $(p>0.05)$ in the same column. Abbreviation: As, Astaxanthin; Ca, Canthaxanthin; Xa, Xanthophyll.

\subsubsection{Color Performance}

Statistical analysis by two-way ANOVA showed that there was a significant difference in the $\mathrm{L}^{*}, \mathrm{a}^{*}$, and $\mathrm{b}^{*}$ values for body skin, abdominal skin, and muscle of bighead catfish in all treatments over the sampling weeks $(p<0.001)$ (Table 3). Fish fed with xanthophyll supplemented diet showed the most yellow color in body skin, abdominal skin, and muscle compared with other diets (Figures 2 and 3). The highest values for the fish fed the Xa diet were achieved at 4 weeks and remained stable or reduced gradually at week 6 . These values were relatively improved and consistent for body skin, abdominal skin, and muscle in all diets after two weeks of the feeding trial. Among the diets, the $\mathrm{L}^{*}$ (Lightness) and $\mathrm{a}^{*}$ (redness) values in the xanthophyll supplemented diet (Xa diet) were significantly lower than in the other treatments, but not significantly compared to the control treatment, while $\mathrm{b}^{*}$ (yellowness) was significantly higher than the control and others treatments $(p<0.05)$.

Lightness values of the body skin, abdominal skin, and muscle of fish are shown in Figure 4. Statistical analysis by one-way ANOVA showed that there were no significant differences in the $\mathrm{L}^{*}$ values of body skin, abdominal skin, and muscle for the control treatment during the feeding trial $(p>0.05)$. The body skin lightness of fish fed with carotenoid supplemented diets showed a slight increase with increasing feeding duration, while the abdominal skin and muscle lightness showed a slight decrease. 
Table 3. $\mathrm{L}^{*}, \mathrm{a}^{*}, \mathrm{~b}^{*}$ for body skin, abdominal, and muscle of bighead catfish during the trial.

\begin{tabular}{|c|c|c|c|c|c|c|c|c|c|c|}
\hline \multirow{2}{*}{ Time (Week) } & \multirow{2}{*}{ Treat. } & \multicolumn{3}{|c|}{ Body Skin } & \multicolumn{3}{|c|}{ Abdominal Skin } & \multicolumn{3}{|c|}{ Muscle } \\
\hline & & $\mathrm{L}^{*}$ & $a^{*}$ & $b^{*}$ & $\mathrm{~L}^{*}$ & $a^{*}$ & $b^{*}$ & $\mathrm{~L}^{*}$ & $a^{*}$ & $b^{*}$ \\
\hline \multirow{8}{*}{2} & Control & $10.8 \pm 1.62 \mathrm{a}$ & $1.89 \pm 0.68^{\mathrm{a}}$ & $2.45 \pm 1.07^{\mathrm{a}}$ & $45.4 \pm 0.38 \mathrm{ab}$ & $17.9 \pm 0.72 \mathrm{~b}$ & $15.6 \pm 0.65^{\mathrm{a}}$ & $40.1 \pm 1.57 \mathrm{~cd}$ & $1.44 \pm 0.33 \mathrm{a}$ & $8.39 \pm 0.84^{\mathrm{a}}$ \\
\hline & As & $13.6 \pm 1.36^{\mathrm{b}}$ & $8.16 \pm 1.45^{c}$ & $6.18 \pm 1.32 \mathrm{bc}$ & $50.8 \pm 0.99 \mathrm{bc}$ & $21.6 \pm 0.87 \mathrm{e}$ & $16.4 \pm 1.06 \mathrm{ab}$ & $41.5 \pm 1.11 \mathrm{de}$ & $1.57 \pm 0.48^{\mathrm{a}}$ & $15.1 \pm 0.50^{b}$ \\
\hline & $\mathrm{Ca}$ & $18.6 \pm 0.86^{\mathrm{d}}$ & $10.7 \pm 0.57 \mathrm{de}$ & $4.99 \pm 0.62 \mathrm{~b}$ & $59.0 \pm 0.19 \mathrm{de}$ & $20.3 \pm 1.04 \mathrm{~cd} \mathrm{e}$ & $17.3 \pm 1.10 \mathrm{ab}$ & $37.6 \pm 1.82^{b}$ & $1.40 \pm 0.27 \mathrm{a}$ & $16.3 \pm 0.93 \mathrm{ab}$ \\
\hline & Xa & $13.5 \pm 1.06^{b}$ & $4.26 \pm 1.18^{b}$ & $9.52 \pm 0.94 \mathrm{e}$ & $40.9 \pm 0.89 \mathrm{a}$ & $21.2 \pm 1.02 \mathrm{de}$ & $18.3 \pm 0.51 \mathrm{ab}$ & $37.9 \pm 1.49 \mathrm{bc}$ & $1.46 \pm 0.34 \mathrm{a}$ & $16.9 \pm 0.53 \mathrm{~b}$ \\
\hline & $\mathrm{As}+\mathrm{Ca}$ & $20.2 \pm 0.54 \mathrm{~d}$ & $12.3 \pm 0.87 \mathrm{e}$ & $6.78 \pm 0.87 \mathrm{~cd}$ & $54.5 \pm 0.53 \mathrm{~cd}$ & $19.7 \pm 0.51 \mathrm{bcd}$ & $15.83 \pm 0.41^{\mathrm{a}}$ & $43.2 \pm 0.55 \mathrm{e}$ & $1.69 \pm 0.30^{\mathrm{a}}$ & $16.2 \pm 0.55 \mathrm{ab}$ \\
\hline & As $+X a$ & $16.3 \pm 1.35^{c}$ & $9.13 \pm 0.82 \mathrm{~cd}$ & $8.24 \pm 1.09$ de & $59.8 \pm 0.43 \mathrm{de}$ & $18.7 \pm 0.67 \mathrm{bc}$ & $16.9 \pm 0.62 \mathrm{ab}$ & $33.9 \pm 0.82 \mathrm{a}$ & $1.60 \pm 0.19 \mathrm{a}$ & $15.8 \pm 0.39 \mathrm{ab}$ \\
\hline & $\mathrm{Ca}+\mathrm{Xa}$ & $16.1 \pm 1.18^{c}$ & $9.47 \pm 0.44 \mathrm{~cd}$ & $7.03 \pm 0.27 \mathrm{c} d$ & $62.9 \pm 8.04 \mathrm{e}$ & $16.2 \pm 1.49^{a}$ & $16.4 \pm 1.99 \mathrm{ab}$ & $43.7 \pm 1.13 \mathrm{e}$ & $1.63 \pm 0.47 \mathrm{a}$ & $15.7 \pm 0.73 \mathrm{~b}$ \\
\hline & Mean \pm SD & $15.6 \pm 1.18^{\mathrm{A}}$ & $8.0 \pm 0.44^{\mathrm{A}}$ & $6.50 \pm 0.27^{\mathrm{A}}$ & $53.3 \pm 8.04 \mathrm{~A}$ & $19.4 \pm 1.49^{\mathrm{A}}$ & $16.7 \pm 1.99 \mathrm{~A}$ & $39.7 \pm 1.13$ & $1.5 \pm 0.47^{\mathrm{A}}$ & $14.9 \pm 0.73^{\mathrm{A}}$ \\
\hline \multirow{8}{*}{4} & Control & $10.9 \pm 1.71 \mathrm{a}$ & $2.12 \pm 0.86 \mathrm{a}$ & $2.70 \pm 0.67 \mathrm{a}$ & $46.1 \pm 1.83 \mathrm{a}$ & $16.1 \pm 0.90 \mathrm{a}$ & $15.6 \pm 1.19 \mathrm{ab}$ & $39.9 \pm 1.52 \mathrm{ab}$ & $1.62 \pm 0.76 \mathrm{ab}$ & $10.4 \pm 1.03 \mathrm{a}$ \\
\hline & As & $25.9 \pm 1.04^{c}$ & $16.2 \pm 1.13 \mathrm{~d}$ & $6.63 \pm 1.19^{c}$ & $51.3 \pm 1.29 \mathrm{~b}$ & $30.1 \pm 0.83 \mathrm{~d}$ & $14.6 \pm 0.81 \mathrm{a}$ & $40.3 \pm 1.18 \mathrm{ab}$ & $1.69 \pm 0.45 \mathrm{abc}$ & $17.2 \pm 1.49^{\mathrm{C}}$ \\
\hline & $\mathrm{Ca}$ & $23.8 \pm 1.01 \mathrm{bc}$ & $9.27 \pm 1.10^{c}$ & $5.10 \pm 0.90^{\mathrm{b}}$ & $54.7 \pm 1.62^{c}$ & $25.7 \pm 1.03^{c}$ & $17.3 \pm 1.36^{c}$ & $41.8 \pm 1.65^{\mathrm{b}}$ & $1.79 \pm 0.47 \mathrm{bc}$ & $18.5 \pm 1.18^{c}$ \\
\hline & $\mathrm{Xa}$ & $22.2 \pm 1.37^{b}$ & $5.15 \pm 0.86^{b}$ & $10.8 \pm 0.87 \mathrm{e}$ & $52.6 \pm 1.38^{b}$ & $22.3 \pm 1.65^{b}$ & $20.4 \pm 0.89 \mathrm{~d}$ & $40.2 \pm 1.07 \mathrm{ab}$ & $1.42 \pm 0.31 \mathrm{ab}$ & $24.2 \pm 1.38 \mathrm{e}$ \\
\hline & $\mathrm{As}+\mathrm{Ca}$ & $25.3 \pm 1.46^{c}$ & $9.99 \pm 0.88^{c}$ & $6.74 \pm 1.02^{c}$ & $55.2 \pm 1.48^{\mathrm{C}}$ & $32.0 \pm 1.53 \mathrm{e}$ & $15.7 \pm 3.29 \mathrm{abc}$ & $41.2 \pm 1.81 \mathrm{~b}$ & $1.56 \pm 0.67 \mathrm{ab}$ & $14.7 \pm 1.52^{b}$ \\
\hline & As + Xa & $24.4 \pm 4.87^{c}$ & $10.2 \pm 5.33^{c}$ & $8.31 \pm 1.51 \mathrm{~d}$ & $54.2 \pm 1.70^{c}$ & $29.9 \pm 1.59 \mathrm{~d}$ & $19.7 \pm 0.57 \mathrm{~d}$ & $39.0 \pm 1.59 \mathrm{a}$ & $2.21 \pm 0.59^{c}$ & $18.5 \pm 1.06^{\mathrm{d}}$ \\
\hline & $\mathrm{Ca}+\mathrm{Xa}$ & $25.5 \pm 5.38^{c}$ & $7.88 \pm 1.44^{\mathrm{c}}$ & $7.83 \pm 1.53 \mathrm{~d}$ & $54.7 \pm 1.71^{\mathrm{C}}$ & $24.9 \pm 1.36^{\mathrm{c}}$ & $17.2 \pm 1.79 \mathrm{bc}$ & $41.9 \pm 3.89^{b}$ & $1.20 \pm 0.45^{\mathrm{a}}$ & $18.9 \pm 1.36^{\mathrm{d}}$ \\
\hline & Mean \pm SD & $22.6 \pm 0.56^{B}$ & $8.70 \pm 1.52 \mathrm{~A}$ & $6.90 \pm 1.00 \mathrm{~A}$ & $52.7 \pm 1.69 \mathrm{~A}$ & $25.9 \pm 0.59 B$ & $17.2 \pm 0.97 \mathrm{~A}$ & $40.6 \pm 3.5$ & $1.6 \pm 0.04 \mathrm{~A}$ & $17.5 \pm 0.55^{B}$ \\
\hline \multirow{8}{*}{6} & Control & $10.2 \pm 1.12 \mathrm{a}$ & $1.27 \pm 0.33^{\mathrm{a}}$ & $2.68 \pm 0.69^{\mathrm{a}}$ & $49.6 \pm 1.23 \mathrm{a}$ & $15.2 \pm 0.85^{\mathrm{a}}$ & $15.9 \pm 1.29 \mathrm{ab}$ & $41.1 \pm 1.12^{\mathrm{b}}$ & $1.53 \pm 0.59 \mathrm{ab}$ & $10.5 \pm 0.82^{\mathrm{a}}$ \\
\hline & As & $21.4 \pm 0.92^{c}$ & $16.3 \pm 0.85^{\mathrm{e}}$ & $6.11 \pm 1.03^{c}$ & $53.2 \pm 1.89$ de & $29.7 \pm 0.99 \mathrm{~d}$ & $16.6 \pm 0.84 \mathrm{~b}$ & $39.5 \pm 1.59 \mathrm{ab}$ & $1.72 \pm 0.86^{b}$ & $17.9 \pm 1.77^{\mathrm{c}}$ \\
\hline & $\mathrm{Ca}$ & $25.4 \pm 1.31 \mathrm{e}$ & $9.54 \pm 0.87 \mathrm{~d}$ & $4.86 \pm 0.79 \mathrm{~b}$ & $52.9 \pm 1.33 \mathrm{~cd}$ & $25.4 \pm 1.51^{\mathrm{c}}$ & $17.8 \pm 1.42 \mathrm{~b}$ & $40.6 \pm 1.27^{b}$ & $1.74 \pm 0.60^{b}$ & $18.8 \pm 1.40^{c}$ \\
\hline & Xa & $18.6 \pm 1.73 \mathrm{~b}$ & $4.43 \pm 1.04 \mathrm{~b}$ & $10.10 \pm 1.21 \mathrm{e}$ & $51.5 \pm 1.60 \mathrm{bc}$ & $23.1 \pm 0.99 \mathrm{~b}$ & $20.9 \pm 1.78^{c}$ & $38.8 \pm 1.46^{\mathrm{a}}$ & $1.23 \pm 0.77 \mathrm{ab}$ & $23.1 \pm 1.03 \mathrm{~d}$ \\
\hline & $\mathrm{As}+\mathrm{Ca}$ & $20.5 \pm 1.38^{\mathrm{c}}$ & $9.75 \pm 0.77 \mathrm{~d}$ & $6.74 \pm 1.02^{c}$ & $54.7 \pm 1.38 \mathrm{e}$ & $30.7 \pm 1.75 \mathrm{~d}$ & $13.6 \pm 1.58^{\mathrm{a}}$ & $40.8 \pm 1.54 \mathrm{~b}$ & $1.74 \pm 0.63 \mathrm{~b}$ & $15.4 \pm 1.74 \mathrm{~b}$ \\
\hline & $\mathrm{As}+\mathrm{Xa}$ & $21.6 \pm 1.22 \mathrm{~cd}$ & $9.19 \pm 1.14 \mathrm{~cd}$ & $8.76 \pm 1.09 \mathrm{~d}$ & $51.1 \pm 1.51^{b}$ & $29.3 \pm 1.72 \mathrm{~d}$ & $20.6 \pm 0.92^{c}$ & $39.9 \pm 1.97 \mathrm{ab}$ & $0.91 \pm 0.87 \mathrm{a}$ & $18.8 \pm 1.76^{\mathrm{c}}$ \\
\hline & $\mathrm{Ca}+\mathrm{Xa}$ & $22.7 \pm 1.46^{\mathrm{d}}$ & $8.51 \pm 0.41^{c}$ & $8.37 \pm 1.29 \mathrm{~d}$ & $54.7 \pm 1.87 \mathrm{e}$ & $26.4 \pm 1.82^{c}$ & $16.1 \pm 6.61 \mathrm{ab}$ & $41.0 \pm 1.39 \mathrm{~b}$ & $1.00 \pm 0.85 \mathrm{ab}$ & $17.3 \pm 1.97^{c}$ \\
\hline & Mean \pm SD & $20.1 \pm 1.91$ B & $8.40 \pm 0.32 \mathrm{~A}$ & $6.80 \pm 1.29 \mathrm{~A}$ & $52.5 \pm 2.08 \mathrm{~A}$ & $25.7 \pm 0.83$ B & $17.4 \pm 3.44 \mathrm{~A}$ & $40.2 \pm 1.93$ & $1.40 \pm 0.66^{\mathrm{A}}$ & $17.4 \pm 0.47^{B}$ \\
\hline
\end{tabular}

Values are mean \pm standard deviation (SD) of triplicates $(n=3) ;{ }^{a, b, c, d, e, A, B}$ are statistical symbols. ${ }^{a}, \mathrm{~b}$ Mean values with difference superscripts in the same column within sampling time (week) are significantly different $(p<0.05$ ); $\mathrm{A}, \mathrm{B}$ Mean values with difference superscripts in the same column are significantly different $(p<0.05)$ in color performance of animal between sampling time (week) by two-way ANOVA. Abbreviation: As, Astaxanthin; $\mathrm{Ca}$, Canthaxanthin; Xa, Xanthophyll.

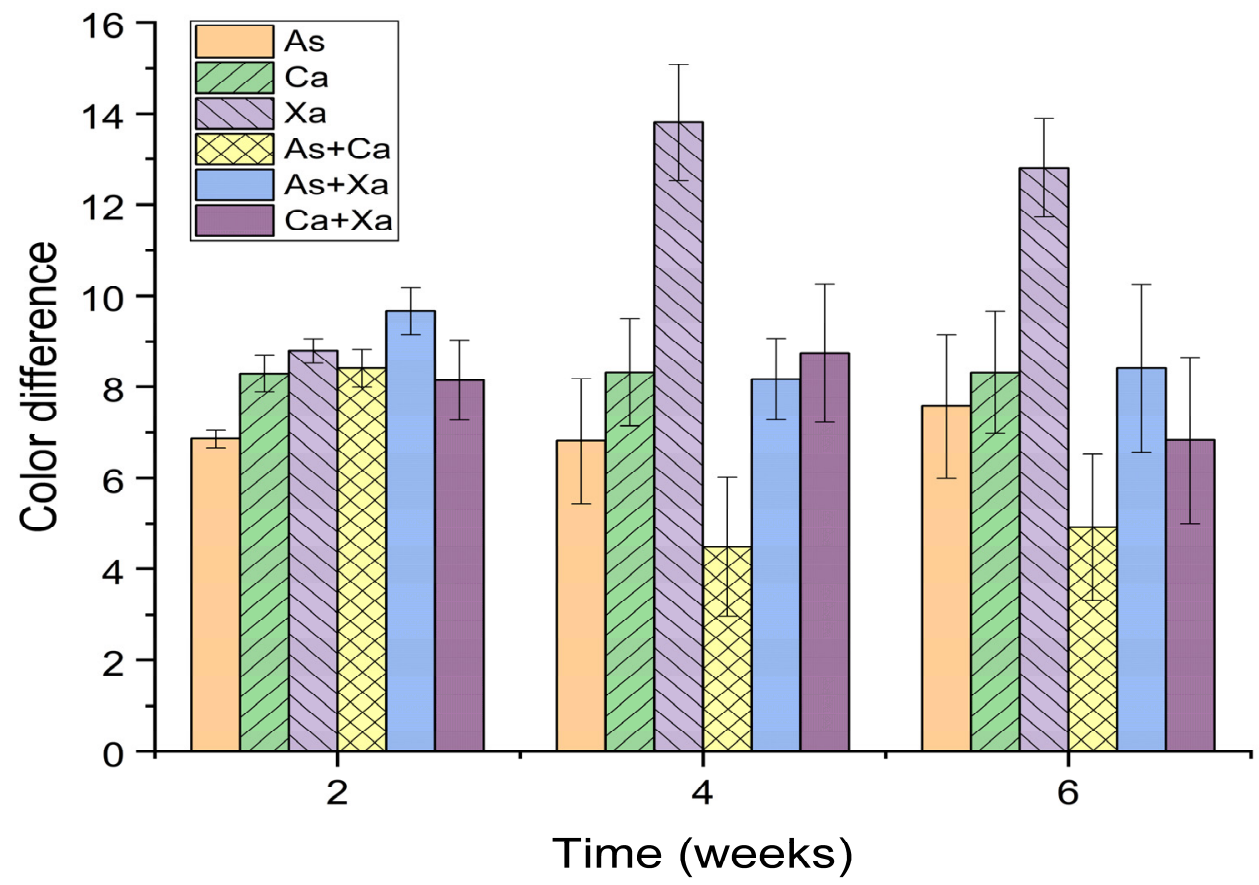

Figure 2. Color performance of bighead catfish fed various dietary pigments at different times of 2, 4, and 6 weeks. Astaxanthin (As), canthaxanthin (Ca), and xanthophyll (Xa). 


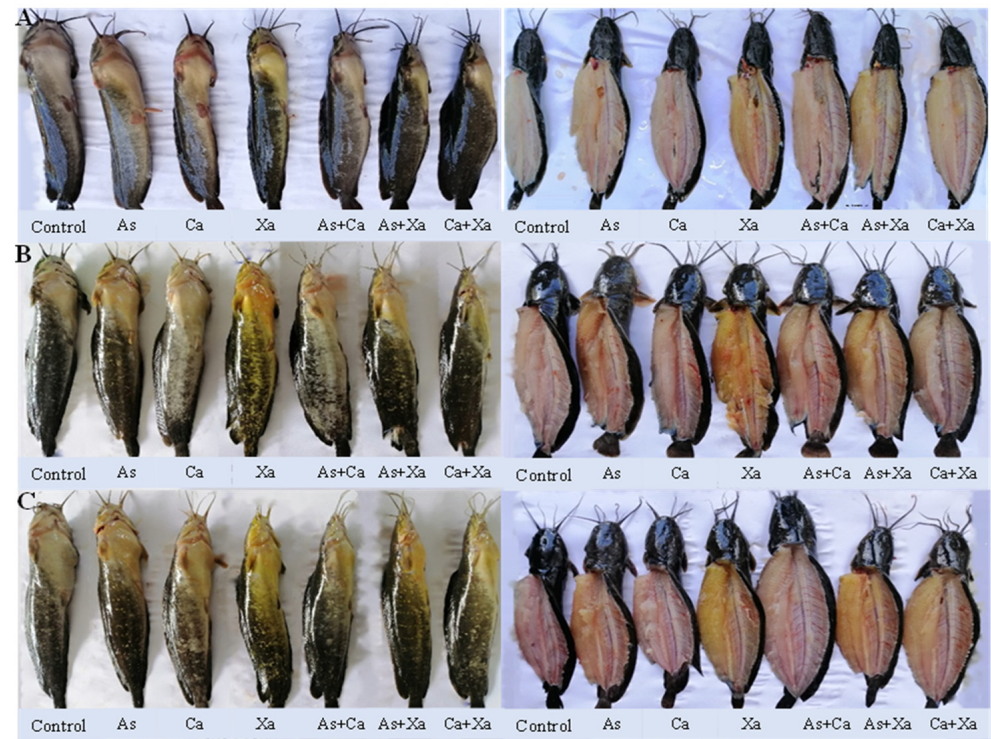

Figure 3. Digital image of body skin and muscle of bighead catfish fed dietary carotenoid pigments for 2 weeks (A), 4 weeks (B), and 6 weeks (C).
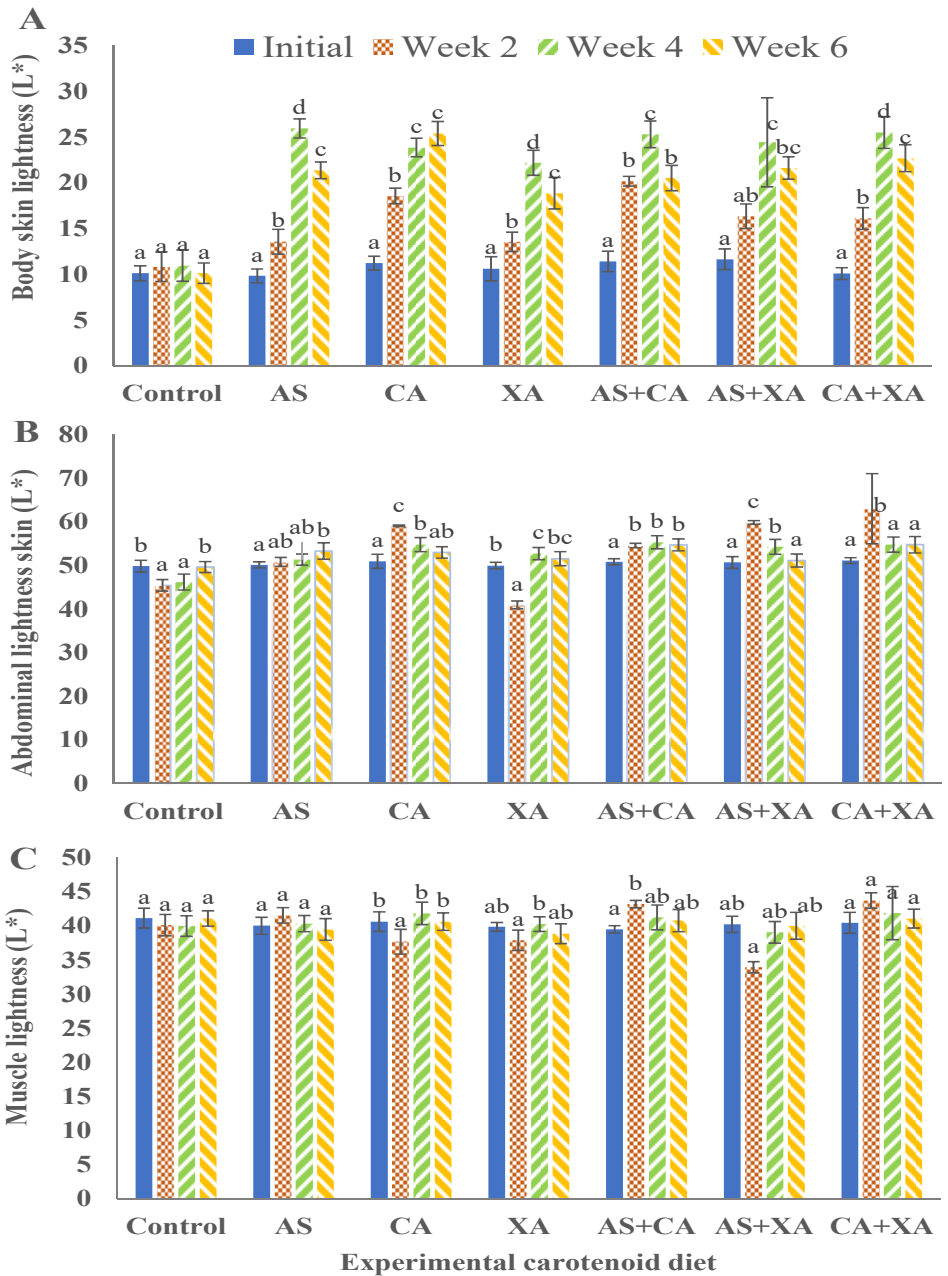

Figure 4. Lightness for body skin (A), abdominal skin (B), and muscle (C) of bighead catfish fed dietary pigments for 2, 4, and 6 weeks. Astaxanthin (As), ccanthaxanthin (Ca), and xanthophyll $(\mathrm{Xa}) .(\mathrm{a}, \mathrm{b}, \mathrm{c})$ Average values of different diets at the same sampling time with different letters are significantly different $(p<0.05)$. Each bar is the mean value of three replicates, three fish per replicate. 
Redness values of the abdominal skin of all treatments tended to increase during the experiment, while this phenomenon did not appear on the body or in muscles tissue (Figure 5). Both $\mathrm{Ca}$ and $\mathrm{Ca}$ combination groups showed lower $\mathrm{a}^{*}$ values on the abdominal skin than those of As and Xa groups at the end of the experiment. As to the redness of the body and abdominal skin, fish fed with carotenoid supplemented diets were redder than those of the control group.

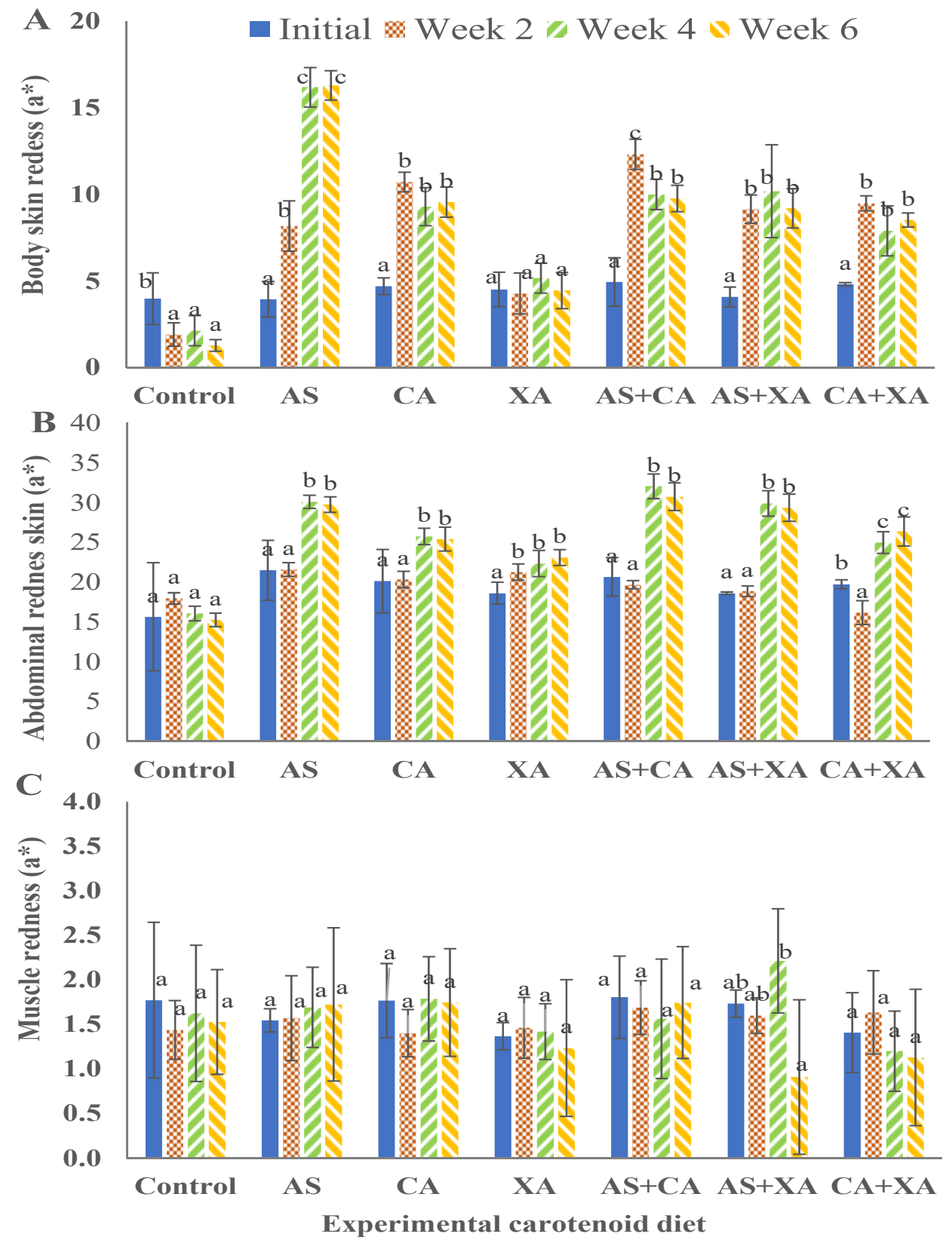

Figure 5. Redness for body skin (A), abdominal skin (B), and muscle (C) of bighead catfish fed dietary pigments for 2, 4, and 6 weeks. Astaxanthin (As), canthaxanthin (Ca), and xanthophyll (Xa). (a, b, c) Average values of different diets at the same sampling time with different letters are significantly different $(p<0.05)$. Each bar is the mean value of three replicates, three fish per replicate.

The yellowness $\left(b^{*}\right)$ values of fish fed with carotenoid pigments supplemented diets tended to increase over the experiment in body skin, abdominal skin, and muscle tissues (Figure 6). The highest body skin yellowness of the Xa group was significantly higher than those of the control group $(p<0.05)$ at 2,4 , and 6 weeks (Figure 6A). However, the $b^{*}$ values of the abdominal skin of fish fed with the control treatment showed no significant 
difference $(p>0.05)$ to those of As, $\mathrm{Ca}$, and/or the combined groups (Figure 6B). In contrast to As and As combination groups, $\mathrm{Xa}$ and $\mathrm{Ca}+\mathrm{Xa}$ groups exhibited significantly higher $b^{*}$ values in muscle tissue. Fish fed with the Xa group reached the highest $b^{*}$ values in muscles at 4 weeks, significantly $(p<0.05)$ higher compared to other groups (Figure $6 \mathrm{C})$.
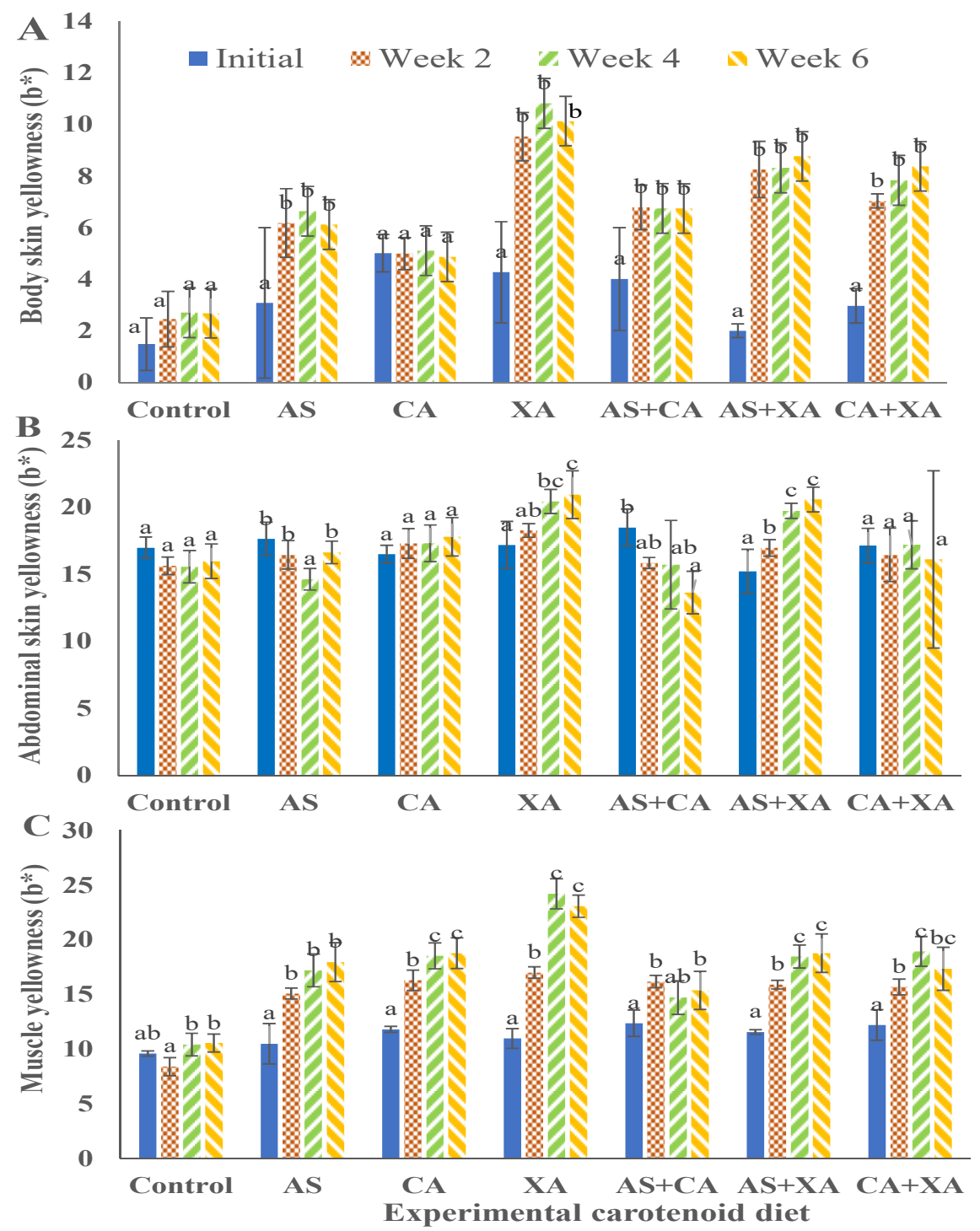

Figure 6. Yellowness $\left(\mathrm{b}^{*}\right)$ value for body skin (A), abdominal skin (B), and muscle (C) of bighead catfish fed dietary pigments for 2, 4, and 6 weeks. Astaxanthin (As), canthaxanthin (Ca), and xanthophyll (Xa). (a, b, c) Average values of different diets at the same sampling time with different letters are significantly different $(p<0.05)$. Each bar is the mean value of three replicates, three fish per replicate.

The sensory evaluation and accumulated carotenoids in the muscle of fish fed with the various pigments diets are presented in Table 4 . Sensory evaluation showed that the body skin and muscle color of the bighead catfish fed Xa diet was the most appreciated, followed by the combination of As + Xa pigments. Statistical analysis showed that there was a significant $(p<0.05)$ color change of fish fed the Xa diet compared with other pigments diets. Similarly, accumulated carotenoid levels in the muscle $(16.89 \mathrm{mg} / 100 \mathrm{~g})$ of fish fed the Xa diet were significantly $(p<0.05)$ higher compared to other treatments. 
Table 4. Sensory evaluation and accumulated carotenoids in the muscle of fish fed various pigments diets after 6 weeks.

\begin{tabular}{|c|c|c|c|}
\hline \multirow{2}{*}{ Treatment } & \multicolumn{2}{|c|}{ Sensory Evaluation } & \multirow{2}{*}{$\begin{array}{c}\text { Accumulated } \\
\text { Carotenoid (mg/100 g }\end{array}$} \\
\hline & Body Skin & Muscle & \\
\hline Control & $6.00 \pm 0.00 \mathrm{e}$ & $6.00 \pm 0.00^{\mathrm{e}}$ & $1.47 \pm 0.27^{h}$ \\
\hline As & $7.13 \pm 0.42^{\mathrm{d}}$ & $7.33 \pm 0.59^{d}$ & $4.75 \pm 0.13^{\mathrm{e}}$ \\
\hline $\mathrm{Ca}$ & $7.11 \pm 0.32^{\mathrm{d}}$ & $7.16 \pm 0.35^{\mathrm{d}}$ & $5.98 \pm 0.23^{\mathrm{d}}$ \\
\hline $\mathrm{Xa}$ & $8.94 \pm 0.24^{\mathrm{a}}$ & $8.89 \pm 0.14^{a}$ & $16.89 \pm 0.60^{a}$ \\
\hline $\mathrm{As}+\mathrm{Ca}$ & $7.28 \pm 0.46^{\mathrm{d}}$ & $7.22 \pm 0.43^{d}$ & $8.70 \pm 0.48^{c}$ \\
\hline $\mathrm{As}+\mathrm{Xa}$ & $8.39 \pm 0.61^{b}$ & $8.39 \pm 0.61^{b}$ & $12.67 \pm 0.11^{b}$ \\
\hline $\mathrm{Ca}+\mathrm{Xa}$ & $7.72 \pm 0.67^{\mathrm{c}}$ & $7.78 \pm 0.73^{\mathrm{c}}$ & $3.91 \pm 0.41^{\mathrm{f}}$ \\
\hline
\end{tabular}

Values are means of three replicate groups' \pm S.D; within a column, values with the same letters are not significantly different $(p>0.05)$. Abbreviation: As, Astaxanthin; Ca, Canthaxanthin; Xa, Xanthophyll.

\subsection{Effect of Dietary Xanthophyll on Growth and Color Performance of Bighead Catfish}

\subsubsection{Growth Performance and Survival}

The growth performance and survival rates of bighead catfish fed different rates of $\mathrm{Xa}$ diet is summarized in Table 5. Statistical analysis showed that there was no difference in the SGR or SR of fish fed various Xa levels $(p>0.05)$. However, feed utilization of the Xa diet at $75 \mathrm{mg} / \mathrm{kg}$ of feed was more efficient than others.

Table 5. Growth performance, initial weight $\left(\mathrm{W}_{\mathrm{i}}\right)$, final weight $\left(\mathrm{W}_{\mathrm{f}}\right)$, specific growth rate (SGR), survival rate (SR), feed conversion ratio (FCR) of bighead catfish fed various xanthophyll diets for 4 weeks.

\begin{tabular}{cccccc}
\hline Treatment & $\mathbf{W}_{\mathbf{i}}$ (g/fish) & $\mathbf{W}_{\mathbf{f}}$ (g/con) & SGR (\%/day) & SR (\%) & FCR \\
\hline Control & $39.5 \pm 0.44$ & $49.9 \pm 1.76$ & $0.46 \pm 0.08$ & $92.2 \pm 1.92$ & $1.38 \pm 0.22$ \\
25 mgXa & $39.1 \pm 0.63$ & $51.8 \pm 1.96$ & $0.40 \pm 0.12$ & $93.3 \pm 5.77$ & $1.38 \pm 0.18$ \\
50 mgXa & $39.3 \pm 1.21$ & $50.3 \pm 1.43$ & $0.43 \pm 0.05$ & $94.4 \pm 1.93$ & $1.34 \pm 0.36$ \\
75 mgXa & $39.6 \pm 0.65$ & $50.8 \pm 1.36$ & $0.48 \pm 0.09$ & $92.2 \pm 1.92$ & $1.05 \pm 0.45$ \\
100 mgXa & $39.0 \pm 0.45$ & $50.8 \pm 1.81$ & $0.49 \pm 0.16$ & $92.2 \pm 3.85$ & $1.11 \pm 0.75$
\end{tabular}

Values are means of three replicate \pm S.D; within a column, values are not significantly different $(p>0.05)$ Abbreviation: As, Astaxanthin; Ca, Canthaxanthin; Xa, Xanthophyll.

\subsubsection{Color Performance}

The color performance of bighead catfish fed various supplementation levels of Xa are shown in Table 6 and Figure 7 . The $L^{*}$ value of the body was statistically significant $(p<0.05)$ compared to the control treatment after 4 weeks. In contrast, the $\mathrm{a}^{*}$ value of the pigment supplemented treatments was reduced. Furthermore, the $b^{*}$ values for fish fed the diets supplemented with $75 \mathrm{mg}\left(b^{*}: 10.6\right)$ and $100 \mathrm{mg}\left(b^{*}: 11.3\right)$ xanthophyll were significantly higher compared with $(p<0.05)$ other treatments.

Table 6. $\mathrm{L}^{*}, \mathrm{a}^{*}, \mathrm{~b}^{*}$ for body skin, abdominal skin, and muscle of bighead catfish fed dietary Xa for 4 weeks.

\begin{tabular}{|c|c|c|c|c|c|c|c|c|c|}
\hline \multirow{2}{*}{ Treatment } & \multicolumn{3}{|c|}{ Body Skin } & \multicolumn{3}{|c|}{ Abdominal Skin } & \multicolumn{3}{|c|}{ Muscle } \\
\hline & $\mathbf{L}^{*}$ & $a^{*}$ & $\mathbf{b}^{*}$ & $L^{*}$ & $a^{*}$ & $\mathbf{b}^{*}$ & $\mathrm{~L}^{*}$ & $a^{*}$ & $\mathbf{b}^{*}$ \\
\hline Control & $50.0 \pm 1.56{ }^{\mathrm{d}}$ & $-0.1 \pm 0.52^{\mathrm{a}}$ & $2.0 \pm 0.58^{\mathrm{d}}$ & $73.1 \pm 1.21^{\mathrm{a}}$ & $-1.6 \pm 0.37^{a}$ & $4.4 \pm 1.60^{\mathrm{d}}$ & $41.4 \pm 1.29^{a}$ & $1.3 \pm 0.36^{\mathrm{a}}$ & $12.9 \pm 1.03 \mathrm{~d}$ \\
\hline $25 \mathrm{mgXa}$ & $52.8 \pm 1.67 \mathrm{bc}$ & $-0.6 \pm 0.18^{a}$ & $5.3 \pm 1.05^{c}$ & $70.8 \pm 1.55^{b}$ & $-3.0 \pm 0.62 \mathrm{~b}$ & $11.4 \pm 1.02^{c}$ & $42.3 \pm 1.61^{\mathrm{a}}$ & $1.2 \pm 1.10^{\mathrm{a}}$ & $17.1 \pm 1.42^{\mathrm{c}}$ \\
\hline $50 \mathrm{mgXa}$ & $51.3 \pm 1.34 \mathrm{~cd}$ & $-1.9 \pm 0.76^{b}$ & $8.0 \pm 0.85 \mathrm{~b}$ & $72.6 \pm 1.57^{\mathrm{a}}$ & $-3.2 \pm 0.73 b$ & $12.9 \pm 1.90 \mathrm{~b}$ & $41.7 \pm 1.45^{a}$ & $1.1 \pm 0.48^{\mathrm{a}}$ & $19.7 \pm 1.68 \mathrm{~b}$ \\
\hline $75 \mathrm{mgXa}$ & $55.2 \pm 1.51^{a}$ & $-3.0 \pm 0.79^{\mathrm{c}}$ & $10.6 \pm 0.93^{\mathrm{a}}$ & $70.7 \pm 1.75^{b}$ & $-3.7 \pm 0.62^{b}$ & $22.7 \pm 1.56^{a}$ & $42.7 \pm 1.70^{a}$ & $1.3 \pm 0.69^{\mathrm{a}}$ & $20.9 \pm 0.64 \mathrm{~b}$ \\
\hline $100 \mathrm{mgXa}$ & $53.4 \pm 1.95^{b}$ & $-3.2 \pm 1.01^{\mathrm{c}}$ & $11.3 \pm 1.89^{\mathrm{a}}$ & $69.9 \pm 0.58 \mathrm{~b}$ & $-3.4 \pm 1.95 \mathrm{~b}$ & $21.4 \pm 1.64^{\mathrm{a}}$ & $41.3 \pm 1.44^{\mathrm{a}}$ & $1.1 \pm 0.34^{\mathrm{a}}$ & $23.1 \pm 1.70^{\mathrm{a}}$ \\
\hline
\end{tabular}

Values are means of three replicate \pm S.D; within a column, values with the same letters are not significantly different $(p>0.05)$. Abbreviation: As, Astaxanthin; Ca, Canthaxanthin; Xa, Xanthophyll. 


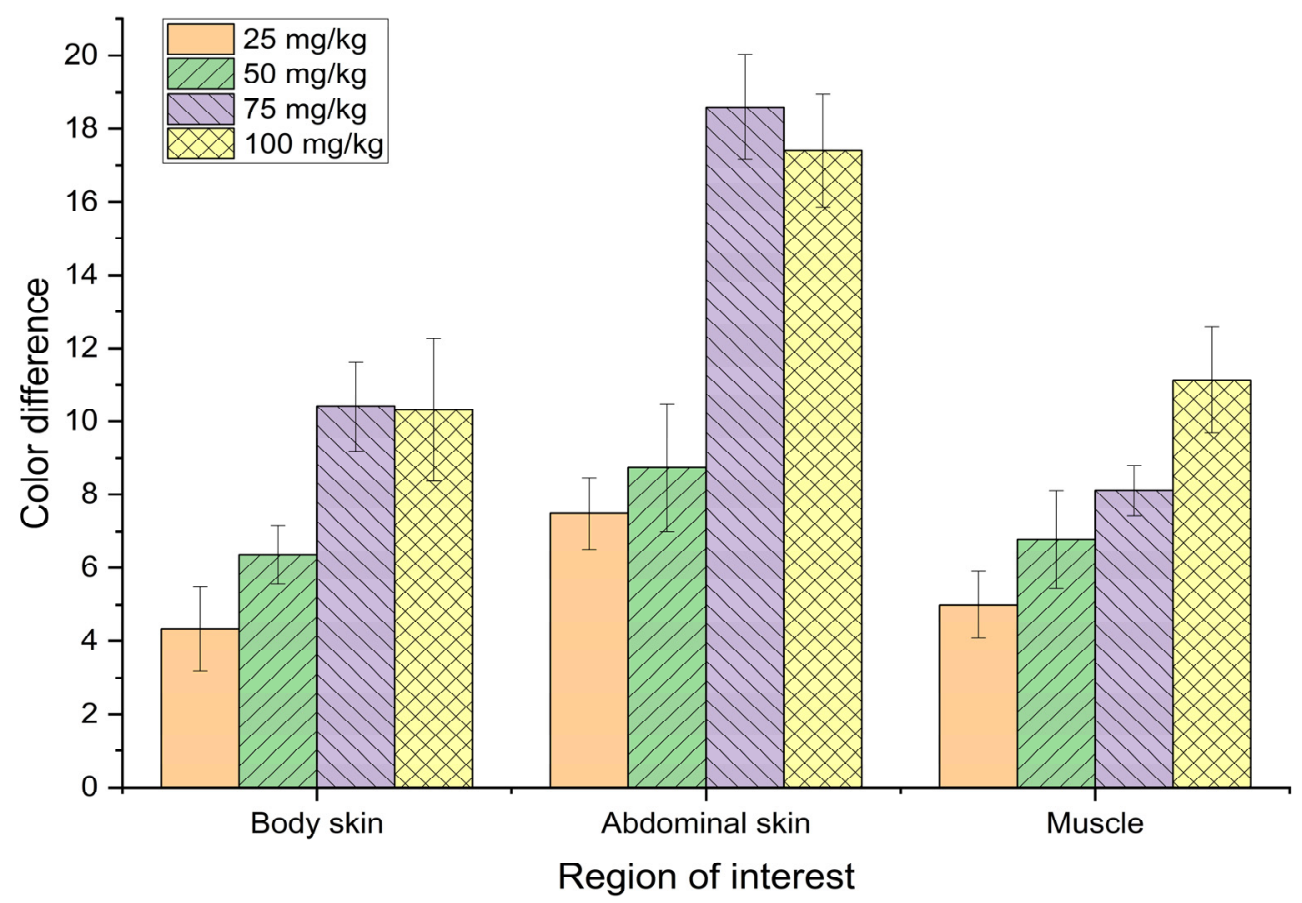

Figure 7. Various colour performance of bighead catfish fed various xanthophyll diets for 4 weeks.

Sensory evaluation and accumulated carotenoids in the muscle tissue of fish fed various levels of xanthophyll in the diet are presented in Table 7 and Figure 8. The highest score was also observed for the body skin and muscle color of those fish fed diets supplemented with $75 \mathrm{mg}$ xanthophyll, followed by the $100 \mathrm{mg} / \mathrm{kg}$ treatment. Carotenoid accumulation in the muscle of bighead catfish fed a diet containing $75 \mathrm{mg} / \mathrm{kg}$ of feed was significantly higher $(p<0.05)$ than other treatments.

Table 7. Sensory evaluation and accumulated carotenoid in muscle of fish fed of bighead catfish fed Xa diets for 4 weeks.

\begin{tabular}{cccc}
\hline \multirow{2}{*}{ Treatment } & \multicolumn{2}{c}{ Sensory Evaluation } & $\begin{array}{c}\text { Accumulated } \\
\text { Carotenoid (mg/100 g) }\end{array}$ \\
\cline { 2 - 3 } & Body Skin & Muscle & $1.30 \pm 0.29^{\mathrm{d}}$ \\
\hline Control & $6.52 \pm 0.51^{\mathrm{d}}$ & $6.00 \pm 0.00^{\mathrm{e}}$ & $2.68 \pm 0.42^{\mathrm{c}}$ \\
$25 \mathrm{mg} \mathrm{Xa}$ & $6.48 \pm 0.51^{\mathrm{d}}$ & $6.52 \pm 0.51^{\mathrm{d}}$ & $6.82 \pm 0.47^{\mathrm{b}}$ \\
$50 \mathrm{mg} \mathrm{Xa}$ & $6.96 \pm 0.76^{\mathrm{c}}$ & $7.11 \pm 0.64^{\mathrm{c}}$ & $16.93 \pm 0.69^{\mathrm{a}}$ \\
$75 \mathrm{mg} \mathrm{Xa}$ & $8.52 \pm 0.51^{\mathrm{a}}$ & $8.56 \pm 0.51^{\mathrm{a}}$ & $16.63 \pm 0.51^{\mathrm{a}}$ \\
$100 \mathrm{mg} \mathrm{Xa}^{\mathrm{an}}$ & $8.00 \pm 0.55^{\mathrm{b}}$ & $8.04 \pm 0.65^{\mathrm{b}}$ & 1.03
\end{tabular}

Values are means of three replicate groups' \pm S.D.; within a row, values with the same letters are not significantly different $(p>0.05)$. Abbreviation: As, astaxanthin; $\mathrm{Ca}$, canthaxanthin; $\mathrm{Xa}$, xanthophyll. 


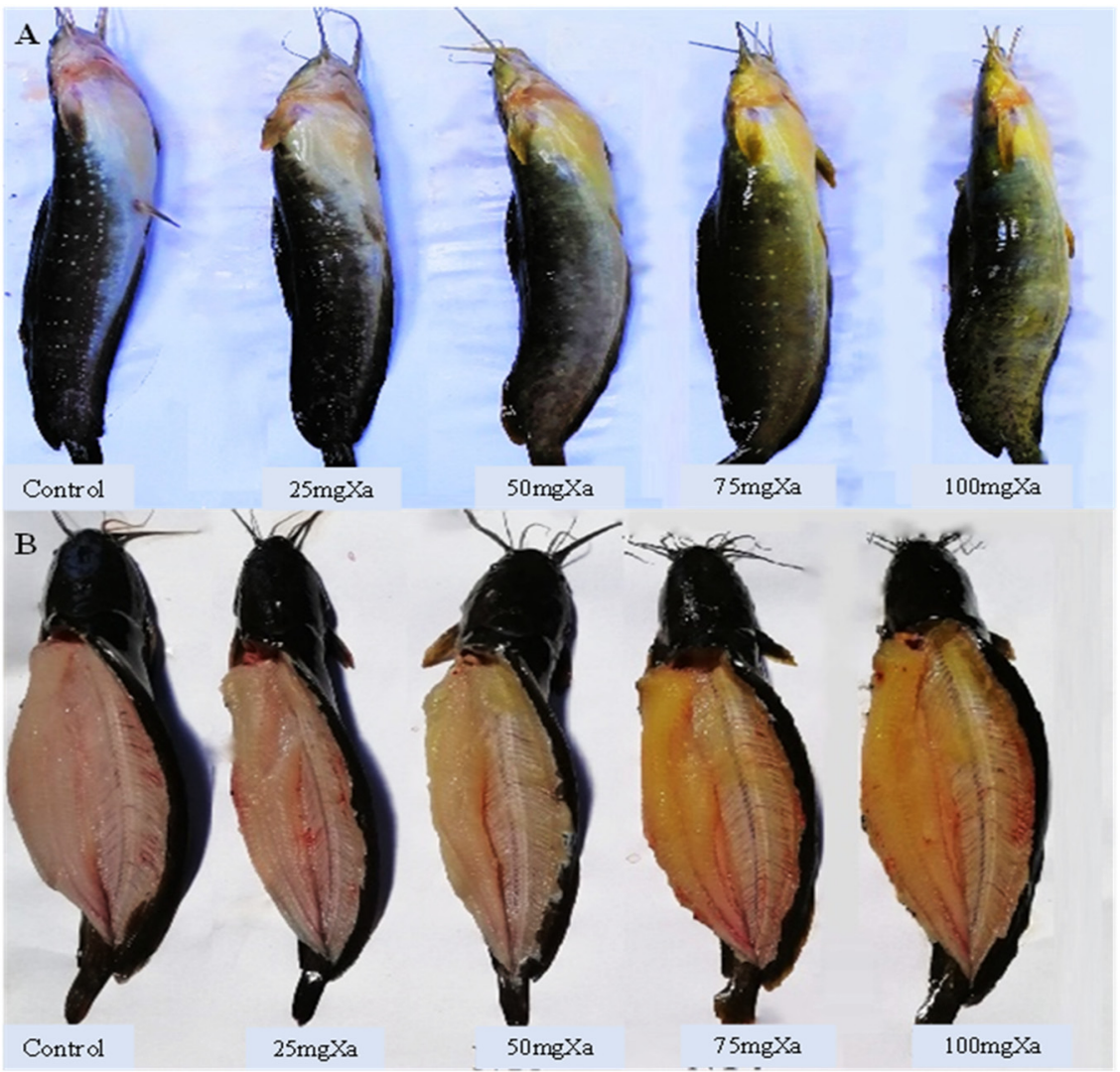

Figure 8. Digital image of body skin (A) and muscle (B) of bighead catfish fed Xa diets for 4 weeks.

\section{Discussion}

Besides color enhancement, carotenoids have also been found to have various other beneficial functions in aquatic species, including the improvement of broodstock performance [30,31], improved disease resistance [32,33], and improved growth performance [34,35]. In the present study, the growth performance and survival rate of bighead catfish were not significantly affected by the dietary supplementation of carotenoid pigments. Similarly, previous studies have also found that supplementing carotenoids into diet did not affect the growth and survival of Atlantic salmon [36,37], rainbow trout [33], gilthead seabream [38], and flame-red dwarf gourami Colisa lalia [20]. The same study was also conducted on yellow cichlid Labidochromis caeruleus. The growth performance and survival of fish was not affected by the xanthophyll diet, and adding xanthophyll to feed may improve the feed coefficient [39]. Moreover, the results of the present study show that the efficiency of feed utilization in fish fed dietary pigments was improved.

The color performance of fish fed dietary carotenoid supplements varies depending on the types and feeding period of the dietary pigmentation [7]. In the present study, statistical analysis by two-way ANOVA showed a clear significant difference in color performance of bighead catfish feeding various types and feeding periods of dietary pigmentation (Table 3). Among diets, bighead catfish displayed a golden yellow appearance after 4 weeks of feeding with a xanthophyll diet and differed significantly compared to fish fed diets containing other carotenoid pigments. The color lasted for 6 weeks (Figures 2 and 3). Another study showed that adding astaxanthin pigment to sea bream feed took 8 weeks [38], whilst adding astaxanthin pigment to flounder feed or adding carotenoids to hybrid catfish feed required 12 weeks [40]. The difference may be due to feed intake and its utilization by fish in the present study compared to previous studies. In agreement with the previous study, the ability to metabolize, absorb, and accumulate the pigmentation in the skin and muscle tissue varies according to the species [7]. 
A high $\mathrm{a}^{*}$ value in the presence of astaxanthin was found in the present study. Bighead catfish is a species characterized by its yellow color, and by adding astaxanthin in this experiment, it lost its natural color because of increased redness. Similar results were found for yellow croakers when combining xanthophyll and astaxanthin [12]. When astaxanthin was added, the red color appeared, and the xanthophyll supplement appeared more yellow. The $b^{*}$ value was yellow; therefore, it had a high value in the treatments with Xa supplementation. Therefore, for improving the appearance and marketability of catfish, a supplement of xanthophyll is suggested because it gives the skin and muscles a yellow color compared to the addition of other carotenoids.

The degree of pigmentation in the muscle tissue of aquatic animals when adding pigmentation to feed depends on the species [7,12]. In the present study, the number of carotenoids accumulated in muscle varied with the type of carotenoid supplied (Table 4). The carotenoid content was lowest in the control group, while higher muscle and carotenoid accumulation were found in treatments supplemented with xanthophyll diet. Similar results were also found in other fish species $[8,34,35,41]$, and additional synthetic pigments and/or natural carotenoids sources also enhanced carotenoid levels in muscle of European seabass [17] and Spinefoot rabbitfish [18]. Other studies reported that fish were better able to accumulate yellow pigments (lutein and zeaxanthin) than red pigments (canthaxanthin and astaxanthin) $[14,42,43]$. The addition of astaxanthin pigment $(120 \mathrm{mg} / \mathrm{kg}$ feed $)$ to the pompano after 30 days showed the clearest color and highest accumulation in fish muscle tissue.

In addition, the sensory evaluation also provided clear support for the yellowness of bighead catfish fed the xanthophyll diet (Tables 4 and 7). In other treatments, where astaxanthin or canthaxanthin (orange) alone were added to the diet, fish had a dark coloring, but the yellow color was not clearly shown. The combination of the two pigments As + $X a$ also gave a golden yellow color with good sensory scores but not as high as Xa alone. Similarly, a combination of astaxanthin and xanthophyll at the ratio of 1:1 also showed an improvement in large golden-yellow croakers [44].

The amount of pigment added to the feed affects the color and level of carotenoid accumulation of fish. At 25 and $50 \mathrm{mg}$ Xa/ $\mathrm{kg}$ of feed, the color of the fish did not meet requirements, as seen by the low sensory score and accumulated carotenoids in the flesh. The $75 \mathrm{mg} \mathrm{Xa/kg}$ application showed the best results in bighead catfish. A similar conclusion on the use and rate of Xa (75 mg) to achieve the best color was reached for the golden croaker [12].

\section{Conclusions}

This study examined appropriate carotenoid pigments, enhancing the color performance of bighead catfish. Dietary xanthophyll showed the best result for color performance after 4 weeks. Adding xanthophyll pigment at a level of $75 \mathrm{mg} / \mathrm{kg}$ of feed over a feeding period of 4 weeks duration is recommended for the achievement of golden-yellow skin and muscle tissue of bighead catfish C. macrocephalus, matching market demands and consumer's appreciation.

Author Contributions: Conceptualization, T.T.T.H. and P.M.D.; methodology investigation, T.T.T.H. and P.M.D.; conducting experiment and data collection, T.V.L., T.L.C.T. and T.M.P.; data analysis, writing and editing, T.T.T.H., P.M.D., H.T.N. and P.T.L. All authors have read and agreed to the published version of the manuscript.

Funding: This study was funded by the Can Tho University Improvement Project VN14-P6, supported by a Japanese ODA loan.

Institutional Review Board Statement: The animal study protocol was carried out in accordance with national guidelines on the protection and experimental animal welfare in Vietnam, Law of Animal Health, 2015 (Report number: VM5068) and Institutional scientific committee of CAN THO UNIVERSITY (Decision No.: 23/QĐ-PMU.VN14-P6). 
Data Availability Statement: The data that support the findings of this study are available from the corresponding author upon reasonable request.

Conflicts of Interest: The authors declare that there is no conflict of interest.

\section{References}

1. Ng, H.H.; Torres, A.G.; Ballad, E.L.; Kesner-Reyes, K. Clarias macrocephalus. The Iucn Red List of Threatened Species 2011:E.T166020a6170044. International Union for Conservation of Nature and Natural Resources, Gland, 2011. Available online: https:/ / doi.org/10.2305/IUCN.UK.2011-1.RLTS.T166020A6170044.en (accessed on 23 September 2017).

2. Aripin, S.-A.; Jintasataporn, O.; Yoonpundh, R. Effects of exogenous melatonin in Clarias macrocephalus male broodstock first puberty stage. J. Aquac. Res. Dev. 2015, 6, 1.

3. Duong, T.-Y.; Nguyen, T.-T.; Pham, T.-L. Morphological differentiation among cultured and wild Clarias macrocephalus, C. Macrocephalus x C. Gariepinus hybrids, and their parental species in the Mekong Delta, Viet Vam. Int. J. Fish. Aqua. Stud. 2017, 5, 233-240.

4. Hien, T.T.T.; Tuan, L.; Tu, T.; Tam, B. Dietary protein requirement of bighead catfish (Clarias macrocephalus gunther, 1864) fingerling. Int. J. Sci. Res.Pub. 2018, 8, 200-205. [CrossRef]

5. Hien, T.T.T.; Hoa, T.T.T.; Liem, P.T.; Onoda, S.; Duc, P.M. Effects of dietary supplementation of heat-killed Lactobacillus plantarum L-137 on growth performance and immune response of bighead catfish (Clarias macrocephalus). Aquacult. Rep. 2021, 20, 100741. [CrossRef]

6. Shahidi, F.; Brown, J.A. Carotenoid pigments in seafoods and aquaculture. Crit. Rev. Food Sci. 1998, 38, 1-67. [CrossRef]

7. Pereira da Costa, D.; Campos Miranda-Filho, K. The use of carotenoid pigments as food additives for aquatic organisms and their functional roles. Rev. Aquac. 2019, 12, 1567-1578. [CrossRef]

8. Torrissen, O.; Hardy, R.; Shearer, K. Pigmentation of salmonids-carotenoid deposition and metabolism. CRC Crit. Rev. Aquat. Sci. 1989, 1, 209-225.

9. An, G.-H.; Bielich, J.; Auerbach, R.; Johnson, E.A. Isolation and characterization of carotenoid hyperproducing mutants of yeast by flow cytometry and cell sorting. Bio/Technology 1991, 9, 70-73. [CrossRef] [PubMed]

10. Hecht, T. Handbook on ingredients for aquaculture feeds-joachim w. Hertrampf and felicitas piedad-pascual. Published by: Kluwer academic publishers (dordrecht). 2000, price: 131.29, isbn 0412627604. Aquaculture 2001, 201, 359-360. [CrossRef]

11. Choubert, G.; Cravedi, J.-P.; Laurentie, M. Effect of alternate distribution of astaxanthin on rainbow trout (Oncorhynchus mykiss) muscle pigmentation. Aquaculture 2009, 286, 100-104. [CrossRef]

12. Yi, X.; Xu, W.; Zhou, H.; Zhang, Y.; Luo, Y.; Zhang, W.; Mai, K. Effects of dietary astaxanthin and xanthophylls on the growth and skin pigmentation of large yellow croaker larimichthys croceus. Aquaculture 2014, 433, 377-383. [CrossRef]

13. Liu, F.; Qu, Y.-K.; Wang, A.-M.; Yu, Y.-B.; Yang, W.-P.; Lv, F.; Nie, Q. Effects of carotenoids on the growth performance, biochemical parameters, immune responses and disease resistance of yellow catfish (Pelteobagrus fulvidraco) under high-temperature stress. Aquaculture 2019, 503, 293-303. [CrossRef]

14. Choubert, G. Response of rainbow trout (Oncorhynchus mykiss) to varying dietary astaxanthin/canthaxanthin ratio: Colour and carotenoid retention of the muscle. Aquacult. Nutr. 2010, 16, 528-535. [CrossRef]

15. Ansari, R.; Alizadeh, M.; Shamsai, M.; Khodadadi, M. Effect of synthetic and algal astaxanthin on the reproduction efficiency of female rainbow trout (Oncorhynchus mykiss). J. Fish. 2013, 26, 15-22.

16. Nhan, H.T.; Minh, T.X.; Liew, H.J.; Hien, T.T.T.; Jha, R. Effects of natural dietary carotenoids on skin coloration of false clownfish (Amphiprion ocellaris cuvier, 1830). Aquacult. Nutr. 2019, 25, 662-668. [CrossRef]

17. Sallam, A.E.; Mansour, A.T.; Srour, T.M.; Goda, A.M.A. Effects of different carotenoid supplementation sources with or without sodium taurocholate on growth, feed utilization, carotenoid content and antioxidant status in fry of the European seabass, Dicentrarchus labrax. Aquac. Res. 2017, 48, 3848-3858. [CrossRef]

18. Mansour, A.T.; El-feky, M.M.M.; El-Beltagi, H.S.; Sallam, A.E. Synergism of Dietary Co-Supplementation with Lutein and Bile Salts Improved the Growth Performance, Carotenoid Content, Antioxidant Capacity, Lipid Metabolism, and Lipase Activity of the Marbled Spinefoot Rabbitfish, Siganus rivulatus. Animals 2020, 10, 1643. [CrossRef]

19. Choubert, G.; Baccaunaud, M. Colour changes of fillets of rainbow trout (Oncorhynchus mykiss w.) fed astaxanthin or canthaxanthin during storage under controlled or modified atmosphere. LWT-Food Sci. Technol. 2006, 39, 1203-1213. [CrossRef]

20. Baron, M.; Davies, S.; Alexander, L.; Snellgrove, D.; Sloman, K. The effect of dietary pigments on the coloration and behaviour of flame-red dwarf gourami, Colisa lalia. Anim. Behav. 2008, 75, 1041-1051. [CrossRef]

21. AOAC. Official Methods of Analysis International, 17th ed.; Association of Official Analytical Chemists: Gaithersburg, MD, USA, 2000.

22. Hunter, R.S.; Harold, R.W. The Measurement of Appearance; John Wiley \& Sons: Hoboken, NJ, USA, 1987.

23. Commission Internationale de l'Éclairage. Colorimetry; Publication CIE No.15; Bureau central de la CIE: Vienna, Austria, 1986.

24. Milovanovic, B.; Tomovic, V.; Djekic, I.; Miocinovic, J.; Solowiej, B.G.; Lorenzo, J.M.; Barba, F.J.; Tomasevic, I. Colour assessment of milk and milk products using computer vision system and colorimeter. Int. Dairy J. 2021, 120, 105084. [CrossRef]

25. Nguyen, C.-N.; Vo, V.-T.; Ha, N.C. Developing a computer vision system for real-time color measurement-a case study with color characterization of roasted rice. J. Food Eng. 2022, 316, 110821. [CrossRef] 
26. Tomasević, I.; Tomović, V.; Milovanović, B.; Lorenzo, J.; Đorđević, V.; Karabasil, N.; Đekić, I. Comparison of a computer vision system vs. Traditional colorimeter for color evaluation of meat products with various physical properties. Meat Sci. 2019, 148, 5-12. [CrossRef] [PubMed]

27. Meilgaard, M.C.; Carr, B.T.; Civille, G.V. Sensory Evaluation Techniques; CRC Press: New York, NY, USA, 1999.

28. No, H.K.; Storebakken, T. Pigmentation of rainbow trout with astaxanthin and canthaxanthin in freshwater and saltwater. Aquaculture 1992, 101, 123-134. [CrossRef]

29. Hatlen, B.; Arnesen, A.; Jobling, M.; Siikavuopio, S.; Bjerkeng, B. Carotenoid pigmentation in relation to feed intake, growth and social interactions in Arctic charr, Salvelinus alpinus (L.), from two anadromous strains. Aquacult. Nutr. 1997, 3, 189-199. [CrossRef]

30. Verakunpiriya, V.; Watanabe, K.; Mushiake, K.; Kawano, K.; Kobayashi, T.; Hasegawa, I.; Kiron, V.; Satoh, S.; Watanabe, T. Effect of krill meal supplementation in soft-dry pellets on spawning and quality of egg of yellowtail. Fish. Sci. 1997, 63, 433-439. [CrossRef]

31. Tizkar, B.; Soudagar, M.; Bahmani, M.; Hosseini, S.; Chamani, M. The effects of dietary supplementation of astaxanthin and $\beta$-caroten on the reproductive performance and egg quality of female goldfish (Carassius auratus). Casp. J. Env. Sci. 2013, 11, 217-231.

32. Christiansen, R.; Glette, J.; Lie, Ø.; Torrissen, O.; Waagbø, R. Antioxidant status and immunity in atlantic salmon, salmo salar 1., fed semi-purified diets with and without astaxanthin supplementation. J. Fish Dis. 1995, 18, 317-328. [CrossRef]

33. Amar, E.; Kiron, V.; Satoh, S.; Watanabe, T. Influence of various dietary synthetic carotenoids on bio-defence mechanisms in rainbow trout, Oncorhynchus mykiss (walbaum). Aquac. Res. 2001, 32, 162-173. [CrossRef]

34. Christiansen, R.; Torrissen, O. Growth and survival of Atlantic salmon, Salmo salar L. Fed different dietary levels of astaxanthin Juveniles. Aquacult. Nutr. 1996, 2, 55-62. [CrossRef]

35. Kalinowski, C.; Robaina, L.; Izquierdo, M. Effect of dietary astaxanthin on the growth performance, lipid composition and post-mortem skin colouration of red porgy Pagrus pagrus. Aquacult. Int. 2011, 19, 811-823. [CrossRef]

36. Baker, R.; Pfeiffer, A.-M.; Schöner, F.-J.; Smith-Lemmon, L. Pigmenting efficacy of astaxanthin and canthaxanthin in fresh-water reared atlantic salmon, Salmo salar. Anim. Feed Sci. Technol. 2002, 99, 97-106. [CrossRef]

37. Olsen, R.; Baker, R. Lutein does not influence flesh astaxanthin pigmentation in the atlantic salmon (Salmo salar L.). Aquaculture 2006, 258, 558-564. [CrossRef]

38. Gouveia, L.; Choubert, G.; Pereira, N.; Santinha, J.; Empis, J.; Gomes, E. Pigmentation of gilthead seabream, Sparus aurata (1. 1875), using Chlorella vulgaris (chlorophyta, volvocales) microalga. Aquac. Res. 2002, 33, 987-993. [CrossRef]

39. Yeşilayer, N.; Mutlu, G.; Yıldırım, A. Effect of nettle (Urtica spp.), marigold (Tagetes erecta), alfalfa (Medicago sativa) extracts and synthetic xanthophyll (zeaxanthin) carotenoid supplementations into diets on skin pigmentation and growth parameters of electric yellow cichlid (Labidochromis caeruleus). Aquaculture 2020, 520, 734964.

40. Lee, K.-J.; Kim, J.-D.; Han, H.-S.; Shin, S.-J.; Kim, S.-S. Effects of dietary spirulina pacifica on innate immunity and disease resistance against Edwardsiella tarda in olive flounder Paralichthys olivaceus. Isr. J. Aquac. 2015, 67, 20716. [CrossRef]

41. Chow, E.; Liong, K.; Schoeters, E. The effect of dietary carotenoids of different forms: Microemulsified and non-microemulsified on the growth performance, pigmentation and hematological parameters in hybrid catfish (Clarias macrocephalus $\times$ Clarias gariepinus). J. Aquac. Res. Dev. 2016, 7, 2.

42. Tejera, N.; Cejas, J.R.; Rodríguez, C.; Bjerkeng, B.; Jerez, S.; Bolaños, A.; Lorenzo, A. Pigmentation, carotenoids, lipid peroxides and lipid composition of skin of red porgy (Pagrus pagrus) fed diets supplemented with different astaxanthin sources. Aquaculture 2007, 270, 218-230. [CrossRef]

43. Li, M.H.; Robinson, E.H.; Oberle, D.F.; Zimba, P.V. Effects of various dietary carotenoid pigments on fillet appearance and pigment absorption in channel catfish, Ictalurus punctatus. J. World Aquac. Soc. 2007, 38, 557-563. [CrossRef]

44. Yi, X.W.; Li, J.; Xu, W.; Zhang, Y.J.; Zhou, H.H.; Smith, A.; Zhang, W.B.; Mai, K.S. Effects of dietary xanthophylls/astaxanthin ratios on the growth and skin pigmentation of large yellow croaker Larimichthys crocea (richardson, 1846). J. Appl. Ichthyol. 2015, 31, 780-786. [CrossRef] 